April 2012

\title{
Requiem for the Prevention of Genocide in Our Time: Working toward an Improbable Possibility but Not Giving Up
}

Israel W. Charny

Follow this and additional works at: https://digitalcommons.usf.edu/gsp

\section{Recommended Citation}

Charny, Israel W. (2012) "Requiem for the Prevention of Genocide in Our Time: Working toward an Improbable Possibility but Not Giving Up," Genocide Studies and Prevention: An International Journal: Vol. 7: Iss. 1: Article 11.

Available at: https://digitalcommons.usf.edu/gsp/vol7/iss1/11

This Articles is brought to you for free and open access by the Open Access Journals at Digital Commons @ University of South Florida. It has been accepted for inclusion in Genocide Studies and Prevention: An International Journal by an authorized editor of Digital Commons @ University of South Florida. For more information, please contact digitalcommons@usf.edu. 


\title{
Requiem for the Prevention of Genocide in Our Time: Working toward an Improbable Possibility but Not Giving Up
}

\author{
Israel W. Charny \\ Institute on the Holocaust and Genocide, Jerusalem
}

\begin{abstract}
In response to the question "Can genocide in our world be stopped to a significant extent," I answer "yes." I propose an International Peace Army (IPA) sponsored by a world government that operates rationally, based on verified news reports and scientific assessments, to respond to mass murders that are in the beginning stages or threats that are gathering. It is very improbable, however, that genocide in our world will be stopped to a significant extent. Global society is not ready to launch an IPA: humankind is still largely governed by totalitarian magic/faith ideological modes, world government is still too much a theater of power seeking, and human beings are still too immoralthat is, they are not committed resolutely to Life over Death for all people. Nonetheless, we cannot afford to give up. Our developing field of genocide studies needs to emphasize efforts at prevention much more. Even if these turn out to be our flailing end-of-species efforts, for me the effort to stop genocide is what gives greatest meaning to being alive while we are.
\end{abstract}

Key words: genocide prevention, human nature, worldwide campaigns for Life against Death

\section{Requiem Overture}

As I reach my 80th birthday and mark close to 50 years as a genocide scholar, this is my autobiographical requiem as it were, including a highly personalized review of the unfolding of the early history of genocide studies as I lived it, a journey through much of my own major work over the years, and yet another-thankfully very brief-consideration of the definition of "genocide." But mainly this article is my emphasis on the efforts we need to make toward the prevention of genocide. I include a list of projects for prevention that I think about from my own vantage point as a psychologist/social scientist/journalist. In the process, I want also to illustrate how each of us as genocide scholars can conceptualize projects for prevention in the respective areas of our own disciplinary expertise.

While, by definition, my overview, such as my remarks on the history of the profession, is not offered as objective truth, but coming from a veteran who was in the heart of it, it should be of interest to colleagues in genocide studies and, better yet, it might be of some inspiration to some younger genocide scholars. From a very early time, in my work I set for myself the two goals to develop my own research on genocide and to contribute to the development of a new multiethnic and multidisciplinary profession of genocide studies.

\section{CAN Genocide in Our World Be Stopped to a Significant Extent?}

Yes. I propose an International Peace Army (IPA) sponsored by a world government that operates rationally, based on verified news reports and scientific assessments of

Israel W. Charny, "Requiem for the Prevention of Genocide in Our Time: Working toward an Improbable Possibility but Not Giving Up," Genocide Studies and Prevention 7, 1 (April 2012): 108-122. ๑ 2012 Genocide Studies and Prevention. doi: 10.3138/gsp.7.1.108 
risks to human lives. ${ }^{1}$ The IPA would be empowered, like a standing local police force, to respond to reports of the beginning of mass murders or gathering threats of imminent mass murder and would move rapidly and promptly to the scene. I believe such an international mechanism could dramatically reduce the incidence of genocidal killing.

\section{WILL Genocide in Our World Be Stopped to a Significant Extent?}

This is improbable. I do not believe that the global society is ready to launch an IPA. Humankind is still highly politicized, conflictual, and polarized between totalitarian magic/faith ideological governance and cultures versus more democratic, empirically based, expert governance and cultures; world government is still too much of a theater of power seeking, power posturing, and scheming; and human beings are still too stupid (meaning anti-empirical) and still too immoral-that is, they are not committed resolutely to Life over Death for all members of the human species.

Nonetheless, we cannot afford to give up, and even if these turn out to be our flailing end-of-species and end-of-planet efforts, for me the effort to stop genocide-and all human-caused death-is what gives greatest spiritual meaning and even sensual pleasure to being alive while we are.

\section{My Bird's Eye View on the Status of Prevention in Genocide Studies Today}

A new graduate student in today's growing number of graduate programs in genocide studies around the world learns that there are dozens of methods and tools to attempt to circumscribe and reduce genocide, to reduce the probability of developing genocides, and even to prevent genocide from occurring. He/she also knows that the success of these tools to date is limited, but the search for new and better methods goes on.

$\mathrm{We}$, the early pioneers of genocide studies, knew very little about how to think of preventing genocide, although we very much dreamed about it and actually tried to develop some means for prevention. However, we were caught up in amassing new knowledge and developing concepts for the description or diagnosis of genocide. There was so much to learn. In addition, in our naïve idealism we were sure that simply spreading knowledge about genocide as a recurrent and universal problem would trigger actual solutions. I believe that our generation of pioneers generated broad global awareness of genocide as a universal problem, but this has not translated into any significant reduction in genocide. We were diagnosticians of the cancers of genocide, but we were not able to find a cure.

It is also to the credit of the first half century of genocide studies that the world has begun to intervene against genocide, as in Kosovo, though efforts are typically poorly thought-out and politically colored. Still, the majority of genocidal situations in the world have not been objects of international intervention, and there is no established basic machinery for intervention. Similarly, our field is just beginning to track the challenge of genocide prevention.

\section{Transitioning Genocide Scholarship from Study and Diagnosis to Treatment Interventions and Prevention}

It is time for genocide scientists to become genocide doctors who are involved in healing, treating, and preventing. There is a long period in clinical research, as in medicine, when we are busy with narrative reports, later with more complex information gathering as we go about developing definitions and naming phenomena, and later still with developing an increasingly scientific assembly of conclusions, facts, and hypotheses for 
further empirical research. That period is over for genocide studies, and it is time to move on to treatment, which includes the development of mechanisms for responding to "early warnings" of genocide and attempting to prevent incipient probabilities of genocidal killing.

The blight of genocide is unbearable. R.J. Rummel's last calculation of genocidal deaths in the twentieth century stood at 260 million human beings ${ }^{2}$ ! Genocide is humanity's top public health problem because it is the most common cause of unnatural human death. ${ }^{3}$

\section{Requiem First Movement: One Scholar's Memory of the Early History of Genocide Studies}

Genocide studies begins with the genius and heroism of Raphael Lemkin. Lemkin pioneered the study of the Holocaust and genocide as organized mass murders. Lemkin's seminal work on the Nazis ${ }^{4}$ is very much written from and alongside his knowledge, concern, and comparative study of many other cases of genocide in human history, with a special awareness of the Armenian Genocide as the first cataclysmic event of genocide in the twentieth century that was then followed by its magnified counterpart, the Holocaust. ${ }^{5}$ Lemkin is clearly the parent of genocide studies, and he literally gives his life to the creation of a first world law against genocide, the United Nations Convention on the Prevention and Punishment of the Crime of Genocide (UNCG). ${ }^{6}$ Regrettably, the ratification of the UNCG by many significant countries, including the United States, took many years. As with many legal documents, ratification has been of limited practical value in the face of leaders who and nations that are hell-bent on killing, and for all of its great pioneering significance, the UNCG itself is conceptually flawed by major omissions of several types of genocidal killing, some of which were proposed by Lemkin himself.7

Lemkin's work focused in large part on generating legal machinery against genocide. He made his first efforts to enact legislation much earlier than the Holocaust in the League of Nations in the 1930s. ${ }^{8}$ Following World War II, during which he was one of the few exceptions in his family to escape death in the Holocaust, he selflessly devoted the remainder of his life-and in some ways his very health and personal life too as he progressively succumbed to illness accompanied by a great deal of personal loneliness - to the enactment and passage of the UNCG.

Even so, and hardly as a criticism of this great man, there is a sense in which even Lemkin's sterling effort also conveys how much we did not know what to do about genocide in a real way. Even a cursory reading of the text of the UNCG shows that the initial concepts for any machinery for prosecuting genocide are as vague and unformed as can be because even Lemkin did not know.

Dutch jurist Peter Drost was next to shine a searchlight on the legal dimensions of genocide, and since there are perhaps no other known works during these years I feel duty-bound to at least refer to his work. But I do not know much about the impact of his writing or that his work included any significant action initiative. Drost strongly criticized the prevailing UN definition of genocide and predicted that governments that set out to commit genocide would push their way through the holes in the definition. Drost proposed a redefinition of genocide that to my mind is a wide-ranging sensible one, quite similar in fact to my own definition, for which I have been criticized over and over again in the literature by formalists and what I call "definitionalists" even as I have simultaneously been complimented by some of the same critics for the humanity of my thinking. In brief, I do not agree to any pile of defenseless bodies being excluded 
from the definition of genocide. Drost proposes, "Genocide is the deliberate destruction of physical life of individual human beings by reason of their membership of any human collectivity as such."9

The next three early genocide scholars to appear on the scene were Irving Louis Horowitz, Leo Kuper, and me. As for the contributions of each member of our trio to concepts of actual intervention and prevention, I think it is clear that each of us cared very much about reducing genocide but did not achieve very much at all. Still at the diagnosis stage, we were not able to offer much in terms of prevention, despite, for instance, my effort to pioneer the concept of a Genocide Early Warning System. Horowitz's Taking Lives: Genocide: State Power and Mass Murder $(1976)^{10}$ focuses on structures of governments that allow and themselves initiate and promote genocidal policies. Horowitz moves us from a time-honored historical methodology of assembling and recounting the facts of what emperors, generals, and governments have done to whomever at whatever times to new ways of describing and interpreting governmental policies and self-interests that make it possible to announce to a people that genocidal killing of such and such targeted victims is legitimate and necessary for one's own military, political, economic, religious, spiritual, or ideological self-defense. In addition, Horowitz has become a leading and devoted publisher of works on genocide. In both ways, Horowitz has made huge contributions to knowledge about genocide.

Leo Kuper produced his seminal work, Genocide: Its Political Use in the Twentieth Century, in 1981. ${ }^{11}$ Kuper, who earlier had provided us with an understanding of the process of polarizations of peoples, including racial and ethnic groups,${ }^{12}$ and an insightful picture of how such conflicts inevitably escalate into reciprocal excesses not only of war but of savage mass murder, published the first work describing and analyzing the structures of different kinds of genocide and provided a number of case histories of genocides. Kuper was the beloved doyen of the emerging academic study of genocide in the early 1980 s.

Kuper's next major book focused directly on prevention. ${ }^{13}$ The book's tone of regret and impotence and writing off of the $\mathrm{UN}$ as a viable force against genocide responded to the reality that the world had done little about genocide and looked unlikely to do much more in the future. It was balanced by a major focus on the concept of prevention and a very practical proposal for a new organization, International Alert (IA), which was to become a worldwide organization for genocide prevention paralleling the Nobel Prize-winning Amnesty International. To head the new international organization Kuper recruited the fabled head of Amnesty-General Martin Ennals who had led Amnesty from its shaky beginnings to Nobel Prize status. ${ }^{14}$ Ennals had earlier invited Horowitz, Kuper, and me to an international meeting of Amnesty in Amsterdam in 1982 to introduce the subject of genocide as a possible future extension of Amnesty's mandate, but the organization turned down this expansion. Ennals later decided to leave Amnesty and devote himself to building IA, but he passed away in 1991 before the work advanced. Kuper's efforts to establish an IA branch in Los Angeles likewise failed to advance before his death in 1994.

My own emerging contribution to genocide studies is represented most strongly in my book How Can We Commit the Unthinkable? Genocide, the Human Cancer, which was published by Westview Press in $1982 .{ }^{15}$ The main thrust of this work was the psychology of the different roles in genocide-victim, bystander, accomplice, and perpetrator. Among other parts of my research for this book, I spent over a year in a sequence 
of psychodramatic exercises that I played out every morning, totally immersing myself in fantasies of victim, bystander, accomplice, and victimizer.

Thus, my book was an exciting first thrust into the psychology of our human readiness to commit the unthinkable. It was also a major platform for my early writing, which I had already begun to publish since $1969,{ }^{16}$ about the shocking evidence of psychological normality-meaning non-psychiatric disturbance-of perpetrators. Likewise, it was a platform for a beginning formulation of a new approach to psychological diagnosis that would put doing harm to oneself and/or doing harm to others at the center of every mental health diagnosis, as opposed to the norm - that still prevails to this dayof focusing on the disturbed functioning of oneself with little to no attention to destructiveness toward others. The book also includes my painful struggles to work out a psychology of our experiences of life and death, especially how human beings seek to bring on the deaths of others as if, in magical thinking, by sacrificing them to the fate of death we fear for ourselves, we guarantee our own survival by their deaths.

In its concluding chapter, the book also offered a major new idea, the concept of a Genocide Early Warning System (GEWS). Pronounced with a soft G, the acronym for me personally was a memory tribute to my people's suffering in the Holocaust and also my wish that we transform the memory of the agony of our Jewish people into a contribution to the prevention of future genocides.

My colleague in Israel, where I had moved from my native US in 1973, Chanan Rapaport, then director of a major think tank in Jerusalem, the Szold National Institute for Research in the Behavioral Sciences, and I met weekly over many years to formulate GEWS. The concept was first published by the Szold Institute in 1977, and the first major publication followed in my 1982 book, ${ }^{17}$ where it earned the respectful recognition and recommendations of a wide range of leaders and institutions, including the Chancellor of Germany, the Premier of France, an Undersecretary of Human Rights in the US State Department, and the United Nations.

Rapaport and I identified 11 Early Warning Processes (EWPs), to which in more recent years I added a twelfth EWP under the influence of Gregory Stanton's inclusion of this stage in his "Eight Stages of Genocide" and following a great deal of my own research and publications on the subject of the denial of genocide. ${ }^{18}$ While all of the EWPs are significant, what Rapaport and I concluded was that one couplet of EWPs was the most frequently recurring in a variety of genocides and in many ways constituted the most powerful force for inciting genocide: the combination of dehumanization and attributing dangerous power (demonization) to the very people whom one is dehumanizing.

Alas, the idea of GEWS was never implemented and the efforts that Rapaport and I made to implement a worldwide Genocide Early Warning System fell flat. Other major scholars then began to emerge in the newly developing field. Among them was Helen Fein who evolved into a giant figure in genocide studies beginning with her awardwinning masterpiece ${ }^{19}$ that analyzed the somewhat different fates of Jews in the Holocaust in relation to the different governmental and cultural norms of various countries in Europe and the extent and ways in which these countries cooperated with evil Nazi directives to turn Jews over to them. Instead of blanket mourning for all Holocaust victims in Europe, and beyond a flat historical narrative, Fein developed a comparative study of the fates of the victims in relation to definable parameters of governments and peoples' cultural traditions. Soon afterward Fein followed up with what I believe to this day to be 
amazingly valuable blank dramatic scenarios of how genocide emerges in different historical sequences..$^{20}$ Along with the continuation of her very creative work in the following years, Fein joined Roger Smith, Robert Melson, and me in founding the International Association of Genocide Scholars (IAGS) in 1994 and became our founding president.

So many wonderfully important scholars followed in the development of genocide studies. Some are strongly identified with the study of their own people's genocides but at the same time they emerge, slowly but surely, as spokesmen and women and supporters of efforts to honor all genocides and work for genocide prevention in general. Outstanding examples include the indefatigable Richard Hovanissian at University of California, Los Angeles, and his major contributions to knowledge of the Armenian Genocide. (In terms of the early history previously given, Hovanissian and Kuper jointly hosted a luncheon to honor Ennals and me at the UCLA Faculty Club in 1988.)

Another major genocide scholar on the center stage was R.J. Rummel, brilliant not only in his amazing compilations of genocide statistics but also in his empirical and theoretical elucidations of the nature of power and the corrective potential of democracy to control destructive power as the single most important issue in social organization. ${ }^{21}$ As a psychologist, I think that the parallel truth is that the healthy control and channeling of needs for power is probably the single most important psychodynamic issue in the mental and spiritual health of individuals.

Although I must arbitrarily end my reminiscences of the early history of our field, I cannot but tip a hat to Henry Huttenbach, who first became an inspired writer of a personal newsletter and then founded the first journal in the field, Journal of Genocide Research. ${ }^{22}$ I also cannot pass over the amazingly productive Samuel Totten whose work I will not discuss here, but I do think that for the fuller history of genocide studies the reader is well referred to two books that are references to keep at hand: Totten and Steven Leonard Jacobs's celebration of Pioneers of Genocide Studies ${ }^{23}$ and Totten and Paul Bartrop's excellent Dictionary of Genocide. ${ }^{24}$

\section{Requiem Second Movement: A Psychologist/Genocide Scholar's Views on the Basic Nature of Homo Genocider}

What do I understand about our human species and our overwhelming readiness to commit genocide?

My requiem statement as a psychologist is that the human being, basically or instinctually, is overwhelmingly available to be cruel and destructive-this immediately alongside all the good facts of a human being's basic desire to live as well as a wonderful readiness to make efforts to protect others' lives.

When I lectured in Israel in 1969 to the Israel Psychological Association and then published a paper in Hebrew in an Israeli journal and another in English in an American journal and when once again in my 1982 book, ${ }^{25}$ I wrote that it was a psychiatrically normal human being who was our common genocider. I was contributing to an emerging new knowledge base that, it turns out, was shocking to many of us.

Two major opinions that first shocked the professional mental health world into the recognition of the essential psychiatric normality of genociders were those rendered by the psychologist and psychiatrist who examined the prisoners on trial at the Nuremberg Trials of Nazis following the end of World War II. The two had plenty grim things to say about the personalities of the Nazi leaders, but in terms of conventional psychiatric concepts - that prevail to this day, in my opinion, most incorrectly—-they were not mentally 
ill. ${ }^{26}$ Some years later, Christopher Browning told the story most vividly and convincingly in his Ordinary Men: Reserve Police Battalion 101 and the Final Solution in Poland. ${ }^{27}$

For many years now, we have known the facts that so-called normal and ordinary people rally in large numbers to follow or give orders to kill masses of other people, let alone that many of them enjoy themselves while doing so. Yet I am far from sure that we have really assimilated the depth of the implications of these empirical facts. I often fantasize that, were I able to find the time in my remaining life, I would author a new basic general psychology book that tells the real story that the human being often is rotten, in a dozen ways of projecting responsibility onto others, hate, prejudice, bigotry, persecution, conformity and collaboration with evil, suicide, terrorism, torture, and mass killing of others.

Personally and professionally as a psychologist, I believe that each and all of these should be defined as pathological in a new healthier diagnostic system in psychology, but the fact is that in contemporary psychiatry unless the person is also acting weirdly in one of the many ways that dysfunction and craziness are manifested, he/she does not earn any psychopathological diagnosis for any of the above behaviors. Believe it or not, even suicide is not a bona fide diagnosis in the current system (depression is but suicide or suicidal behavior are not).

In general, I have proposed in a series of professional publications on mental health ${ }^{28}$ that all psychiatric and psychological diagnoses should be based, routinely and automatically, on diagnosing two vectors:

1. Is the person harming his/her own life? Beyond a certain extent this is to be defined as psychological disturbance, and basically this is what the present diagnostic system does do.

2. Is the same person harming the life of another person or other persons? How much so? How dangerously? Beyond a certain extent this should also be defined as psychological disturbance, and the present system largely does not do this.

In my proposal, either disturbance and combinations of the two can be the basis for a definition of abnormality. Further, I emphasize that either vector can be easily transformed into the other. One can murder millions while looking and acting super competent and therefore, in current language, as if one were quite mentally healthy, and only later in the process of the madness of power and destruction of life do symptoms of personal disorganization and self-hurting appear, but in my view the disturbance was there from the beginning of hurting others.

I propose that the central basis of all psychological health is respect for and protection of life-one's own and the lives of others as well. And the common denominator of dysfunction and psychopathological disturbance is violating, hurting, and destroying human life-one's own or the lives of others.

Lest there be any confusion, I also emphasize that beyond a certain point of hurting others there can be no resort to a defense of psychological illness and the perpetrator must face criminal charges.

Although my proposal has been referenced often enough in mental health literature and reviewed positively by many-and I do not know of any major critique of the concept in psychological literature-there has not been any move whatsoever toward its recognition or adoption in official systems. In psychology, and in our Western culture at large, the illusion that human beings are basically good, emotionally healthy, and decent goes on and on in the face of hundreds of millions dead from genocide against 
unarmed people or in the face of brilliant psychological research such as Stanley Milgram's work on obedience to authority ${ }^{29}$ - participants in Milgram's study gave dangerous electric shocks on the order of the experimenter-or Philip Zimbardo's work on how many ordinary, presumably "normal" and apparently decent people turn into vultures if given jailer status and power. ${ }^{30}$

\section{Choice: The Key to Individual and Collective Policies toward Life over Death and for the Prevention of Genocide}

The model that Rappaport and I created in How Can We Commit the Unthinkable? has two parallel components. The first describes basic psychological processes and how the same EWPs we are to use in the early warning system for collective groups are deeply rooted in the inherent construction of the human mind and human experience (e.g., the quite natural need we have to identify threats to our survival and fight back in what we sincerely believe to be self-defense or the needs to experience power, including power over others). The second component presents the EWPs in the societal system that we have identified as likely to culminate in genocide. The EWPs are described as extending and amplifying basic mind processes that are seen in each individual's psychology all though life. Genocidal behavior is not a freak that descends out of the blue. It comes up from the basic primary workings of the human mind and soul. ${ }^{31}$

The overriding key is choice - that is, the capacity of the human mind to decide to stop, including stopping violence. Every collective-including religious movements, political movements, and nations-must exercise such choices. We are all doing so either knowledgably or inadvertently and unconsciously, but we are making choices. While many people and collectives make positive choices, many make negative ones, whether they see their actions as positive or not and whether they intend their actions to escalate to killing or not.

Thus, a basically democratic nation embarks on its independence joyously, seeking the freedom and welfare of its citizens, but in the course of its experiences-say of being attacked by others and needing to invoke self-defense-and in the course of the development of conscious and unconscious interests in becoming superior to other peoples and exploiting or enslaving others, even a largely good nation can produce its share of genocidal My Lais in Vietnam and Deir Yassins in Israel-Palestine in the course of military operations basically devoted to self-defense. Patterns of colonial genocidal crimes can spring without prior malevolent intentions as land and resources are taken from indigenous peoples. Genocidal murders can take place in the course of wars, even just wars, as against Germany (e.g., Dresden) and Japan (certainly the nuclear destruction of Nagasaki and perhaps also Hiroshima). In addition to genocide by "good" guys, the less democratic countries stride more easily and rampantly to genocidal actions against endless numbers of people in the Tibets, Chechnyas, Yugoslavias, Cambodias, and Rwandas.

\section{Requiem Third Movement: Promoting the Prevention of Genocide in the Emerging Field of Genocide Studies}

\section{Should the Concept of Genocide be Replaced?}

Alternative words or concepts such as "extremely violent societies," "atrocity crimes," "ethnic cleansing," "democide," and "crimes against humanity" can each add valuable meanings to our understanding of aspects of a genocidal event and provide us with a fuller language for classifying different types of genocide, but I am against seeking to 
replace the vital word genocide. First of all, this is the word that has successfully drawn easy consensual use in the languages of people around the world. What they mean by it in common-sense language is that some killing leader/group has murdered masses of defenseless civilians. In my judgment, that is exactly what Lemkin's word construction was really intended to offer-a way of naming and describing mass murders of civilians under any and all circumstances.

\section{The Energy of the Field Needs to Move from Definitionalism to a Real Concentration on Prevention}

Genocide studies should be defined today explicitly and prominently as a field of study as well as research and action for intervention and prevention. Prevention should be at the center. For all my work in this field, soon to be 50 years, ${ }^{32}$ obviously I still don't know very much about preventing genocide. Be that as it may, I believe that we have reached the point at which we can think and plan a great number of prevention projects and initiatives and, through trials, successes, and failures, there will come a future era when human civilization will have developed significant tools to achieve a meaningful degree of prevention..$^{33}$ In contrast to the past, the goal of learning and contributing to prevention efforts should now be built into every graduate program in Holocaust and genocide studies.

I have no doubt that the international and national legal systems sit at the forefront of possible genocide prevention. I celebrate the several noteworthy steps that have already been taken, such as the creation of the United Nations tribunals on the genocides in Rwanda and in the former Yugoslavia and the creation of the International Criminal Court (ICC). Yet I worry about the continuing definitionalism ${ }^{34}$ in legal circles that builds on the wasteful polemics of many genocide scholars who keep searching for a "pure" definition and proof of "pure" intentional genocide and are willing to skip past millions of dead bodies that are hardly anything but other versions and categories (or types) of genocidal mass murder.

\section{One Genocide Scholar's Nominations of Projects for Genocide Prevention}

I wish to propose a series of serious projects, but I also want this list to illustrate a larger point that in every discipline there await many possibilities for creative efforts at genocide prevention. By combining proposals from the many disciplines that are involved in genocide studies, we will have a dazzling array and agenda for future work in our field that moves us beyond the successful first era of basic understanding.

Each of us, and each of our disciplines, must contribute ideas and tools for prevention based on our areas of expertise. As a psychologist and social scientist, as well as a journalist/writer, with deep interests in and a great deal of experience with information systems and public communication, it is to be expected that I propose projects mainly along these lines. Below are some of my ideas for projects toward the goal of genocide prevention.

1. Proposal for an international peace army: an integrated use of military force, public medical and health programs, and informed tools of community organization to organize regions and cultures for life and against death-making, including longterm prejudice and persecution of others.

2. Information systems and early warning systems that alert us to possible developing genocides and direct us to seek possible interventions that might reduce and limit the dangers of mass deaths. 
a. Genocide Early Warning Systems, ${ }^{35}$

b. World genocide situation rooms in major Holocaust and genocide museums, ${ }^{36}$ and

c. Genocide Prevention Now, ${ }^{37}$ an online magazine that provides information about genocide in our world and about developments in genocide studies and prevention.

3. Worldwide promotional campaigns for life and against seeking death: life protection needs to become a more consensual human value. Using a wide range of information and media tools, with the leadership and participation of a wide range of acknowledged public heroes, including many different religious leaders, I propose a series of campaigns to elevate the value of life. The goals of the campaigns are to promote respect for life and commitments to the right to life of all people, and wholesome life-protecting social and ecological environments. Death-seeking, such as genocidal terrorism or totalitarian murders of citizens, must become a forbidden act in the basic consensus of human minds all over the globe. This could include the formation of a new organization, "Right to Life" (R2L), based first of all in a coalition of victim peoples of past genocides who will be joined by other people of good will to promote the goal of a right to life for all human beings.

4. Legislation against incitement to violence and genocide: European countries have several criminal laws against denials of established past genocides, but Americans oppose them as violations of the cardinal principle of free speech. I suggest that in the US too there can be room for further legislation against incitement to violence, including the blatant celebration or legitimization of past genocides and denials of past genocides which convey manifest calls to renew violence against the same or other peoples. ${ }^{38}$

5. International licenses for leaders of national governments: a program that awards annual international licenses to leaders of national governments on the basis of their proven histories and current policy assertions of firm commitments against genocidal policies and terrorism. Only nations with qualified licensed leaders will then be eligible for a range of international economic privileges and programs.

Clearly each of the above proposals merits an essay in its own right. For the purposes of the present overview, I will confine myself to some additional comments on worldwide culture campaigns for Life over Death. With respect to the other suggested projects, in a few cases I offer some introductory explanations in the notes and direct the reader to some bibliographic resources.

\section{Comments on the Proposal for Worldwide Promotional Campaigns for Life and against Death}

I have previously described a worldwide campaign for the Right to Life of all peoples in my book on the psychology of suicide bombers. ${ }^{39}$ I then expanded this proposal to formulate a cardinal principle of $R 2 L$ or the Right to Life of Every Human Being and the hope that such a principle could inspire millions of human beings around the world and become a consensual principle of most of humanity, and I propose the creation of a new worldwide organization: R2L! A Worldwide Union of Genocide Victim Peoplesand All Caring People-On Behalf of a Right to Life of All Peoples. ${ }^{40}$

The proposed concept of $\mathrm{R} 2 \mathrm{~L}$ should be immediately recognized as a companion to the historic proposal of $\mathrm{R} 2 \mathrm{P}$ or the Responsibility to Protect, which was put forward 
by Gareth Evans, former Foreign Minister of Australia, and Mohamed Sahnoun, Special Advisor to the UN Secretary-General. ${ }^{41}$ The International Commission on Intervention and State Sovereignty issued its report in December 2001. It has been adopted by the UN and has been considered by many to be a momentous breakthrough in human thinking and the value system of the international community. On a legal level, it is a breakthrough concept that goes against a belief that countries are not responsible to intervene in the domestic affairs of other nations and instead stipulates that each nation has no less than a responsibility to intervene on behalf of saving human lives when it becomes clear that the government of another nation is failing to do so or is actively involved in mass killing.

I envision R2L as a major international office conducting international cultural campaigns on behalf of the sanctity of life and commitment to protecting human life in projects conveyed in the different languages of our world and through the various cultural forms known and trusted by different peoples, including religious leaders, as well as through activities, folk art, music, and more. I also see such an organization undertaking or supporting a variety of major action projects such as those I sketched above. R2L is the antithesis and antidote to the Culture of Death. Osama bin Laden was quoted as saying "We love death. The U.S. loves life. That is the difference between us two." 42

\section{The Necessary Authenticity and Scientific Validation of Information and the Battle against Denial and Falsehoods}

A cardinal rule for any R2L project or activity must be the authenticity and scientifically established validity of information, for which purpose it is not difficult to establish clear procedures for ruling on the admissibility of information, such as the use of multiple multiethnic and multidisciplinary evaluation committees working in parallel but entirely separately from one another and protected to the utmost from political pressures from any source. In the course of working with information about past genocides, it is inevitable that data will also be presented about the execution of genocidal massacres and even larger genocidal campaigns by some victim peoples. ${ }^{43}$ For all that, we legitimately remain strongly identified with our sorrow and anger at our having been victims of genocide. The facts and critiques of the faults and errors of our various peoples must be dealt with responsibly and respectfully.

The endless denialist propaganda in the world cannot be ignored. It is not difficult to establish clear procedures for ruling on the inadmissibility of openly false misinformation and propaganda, and there is no reason that the world community has to continue entertaining intentionally denialist claims by anyone, including governments, as if they deserve a fair hearing as "the other side" of the story, a "competing narrative," or an alternative view that has to be "researched" further.

\section{Requiem Finale: A Call for Integrity and Commitment in Genocide Studies}

I have been too often disappointed by leaders in our field of genocide studies. Naively, but idealistically, I expected a higher level of personal ethics and comportment in our profession, which after all is committed to stopping the scourges of all sorts of claims of superiority and power over others and attacks against other people. I remember vividly Kuper's amazement and unbearable hurt when he ran into a hunger for power and superiority on the part of individuals and agencies in our young field rather than an inspiration of caring to stop genocidal killing. I think our discipline needs to devote some time to the creation of a professional code of ethics and a review machinery to 
help constructively process complaints and angers that arise in the course of our work with one another.

Since life makes no sense to me unless it is for serving life, beginning with my own safety and health and also the safety and health of others, I am happy and devotedly committed to advancing efforts (my own as well as those of others) to work toward genocide prevention. Even though we are not going to make it in our time, or perhaps ever, this is the only way I want to live and die.

Israel W. Charny is widely respected and credited as a prime mover in the development of genocide studies. In 1980 he founded the first institute and in 1982 he organized the first international conference. He is a co-founder and past president of the International Association of Genocide Scholars; he edited the first encyclopedia on genocide; and is currently editor of GPN: Genocide Prevention Now.

\section{Notes}

1. Israel W. Charny, “An International Peace Army: A Proposal for the Long-Range Future,” Encyclopedia of Genocide, ed. Israel W. Charny, 2 vols. (Santa Barbara, CA: ABC-Clio Publishers, 1999), 649-54. The Encyclopedia was awarded "Outstanding Academic Book of the Year" in 2000 by the American Library Association.

2. R.J. Rummel, "Revaluating World Democide to be 262 Million," E-mail to list selected by Rummel, 11 Dec 2005.

3. The concept of genocide as a public health problem was first articulated by a University of California social psychologist and his colleague: Marc Pilisuk and Lyn Ober, "Torture and Genocide as Public Health Problems," American Journal Orthopsychiatry 46,3 (1976): 388-92. Pilisuk termed genocide "Public Health Problem Number One." In recent years, epidemiologist Elihu D. Richter, Hebrew University of Jerusalem Hadassah Medical School, has written forcefully on the same concept. See Elihu D. Richter, "Anti-semitism, Public Health and Genocide: From Racial Hygiene to the Culture of Death," GPN: Genocide Prevention Now 6 (winter 2011), http://www.genocidepreventionnow.org/Home/GPNISSUES/ Issue6Spring2011/tabid/109/ctl/DisplayArticle/mid/398/aid/296/Default.aspx (accessed 14 Feb 2012).

4. Raphael Lemkin, Axis Rule in Occupied Europe: Laws of Occupation, Analysis of Government, Proposals for Redress (Washington, DC: Carnegie Endowment for International Peace, 1944).

5. See Raphael Lemkin, "Totally Unofficial," undated, the Raphael Lemkin Papers, Box 2: Bio- and Autobiographical Sketches of Lemkin, Manuscript and Archives Division, New York Public Library. See selections from the unpublished papers in Raphael Lemkin, Raphael Lemkin's Thoughts on Nazi Genocide: Not Guilty?, ed. Steven L. Jacobs (Lewiston: Edwin Mellen, 1992).

6. Convention on the Prevention and Punishment of the Crime of Genocide, 9 December 1948, 78 U.N.T.S. 277, http://www.preventgenocide.org/law/convention/text.htm (accessed 6 Feb 2012).

7. These include genocide of one's own people, politicide, transnational genocidal terrorism, and ecological genocide.

8. Raphael Lemkin, "Acts Constituting a General (Transnational) Danger Considered as Offenses Against the Law of Nations" (special report presented at the 5th Conference for the Unification of Penal Law, Madrid, 14-20 Oct 1933). Raphael Lemkin was a lecturer on comparative law at the Institute of Criminology of the Free University of Poland and Deputy Prosecutor of the District Court of Warsaw.

9. Pieter Drost, The Crime of State, 2 vols. (Leyden: A.W. Sythoff, 1959).

10. Irving Louis Horowitz, Taking Lives: Genocide: State Power and Mass Murder (New Brunswick, NJ: Transaction, 1976).

11. Leo Kuper, Genocide: Its Political Use in the Twentieth Century (London: Penguin, 1981).

12. Leo Kuper, The Pity of It All: Polarization of Racial and Ethnic Relations (London: Duckworth, 1977).

13. Leo Kuper, The Prevention of Genocide (New Haven: Yale UP, 1985).

14. See "Martin Ennals," Encyclopedia of Genocide, 360; Samuel Totten and Paul Bartrop, "Martin Ennals," in Dictionary of Genocide, ed. Samuel Totten and Paul Bartrop, vol. 1 (Westport, CT: Greenwood, 2007), 13.

15. Israel W. Charny in collaboration with Chanan Rapaport, How Can We Commit the Unthinkable? Genocide, the Human Cancer (Boulder, CO: Westview, 1982). The book was republished in 1983 with a change to the title: Genocide, the Human Cancer (New York: Hearst Books, 1983).

16. Israel W. Charny, "Normal Man as Genocider" (paper presented to Israel Psychological Association in Hebrew, 1969). An updated version is Israel W. Charny, "Normal Man as Genocider," in Charny and Rapaport, How Can We Commit the Unthinkable?, 9-28. 
17. Israel W. Charny in collaboration with Chanan Rapaport, Genocide Early Warning System (GEWS), pamphlet by the Szold National Institute for Research in the Behavioral Sciences, Jerusalem, 1977. See also the subsequent major publication, Israel W. Charny in collaboration with Chanan Rapaport, "Toward a Genocide Early Warning System," in Charny and Rapaport, How Can We Commit the Unthinkable?, 283-331; Charny in collaboration with Rapaport, “Appendix A: The Flow of Normal Life Experience Processes in Individuals, Families, Groups and the Societal System that Can Culminate in Genocidal Destructiveness," in Charny and Rapaport, How Can We Commit the Unthinkable?, 344-7.

18. Gregory Stanton, "The 8 Stages of Genocide," http://www.genocidewatch.org/genocide/8stagesofgenocide.html (accessed 15 Jan 2012) [Originally presented as a briefing paper at the US State Department in 1996].

19. Helen Fein, Accounting for Genocide: National Responses and Jewish Victimization during the Holocaust (New York: Free Press, 1979).

20. Helen Fein, "Scenarios of Genocide: Models of Genocide and Critical Responses," in Toward the Understanding and Prevention of Genocide, ed. Israel W. Charny (Boulder, CO: Westview, 1984), 3-31.

21. R.J. Rummel, "Power Kills: Absolute Power Kills Absolutely," Internet on the Holocaust and Genocide, 38 (1992); R.J. Rummel, Power Kills: Democracy as a Method of Nonviolence (New Brunswick, NJ: Transaction, 1997).

22. The professional and political story of the Journal of Genocide Research (JGR) begins with Henry Huttenbach's wonderful contribution to the field in founding the journal, editing it, and producing it for several years. There were serious problems during this period with respect to Huttenbach's failing and refusing to have articles peer reviewed and his editorial management, which did not provide much feedback to authors even with respect to when their accepted article would be published (the waiting could mount up to years). Nonetheless, it was clear that a high-quality journal was being produced for our new field.

There came a point when signals were coming from Huttenbach about his desire to transfer journal management to others. We at the IAGS (Robert Melson was president at the time and I was vicepresident) were interested in creating a journal, and we proceeded to enter into serious negotiations with Huttenbach, including through the services of a Washington law firm which labored for some months over successive drafts of an agreement that was being negotiated. What was to unfold was a sorry story that Huttenbach had already entered into an agreement months earlier with those who were preparing to launch the then-named European Network of Genocide Scholars (ENoGS).

The launching of ENoGS itself was also kept secret, and when it was finally announced it proceeded without any consultation, collaboration, or communication with IAGS - the professional organization many of us had nurtured so arduously and devotedly since its inception. JGR became ENoGS's journal. Jürgen Zimmerer, who was the founding president of ENoGS, has held that position since its foundation without any election process for membership.

The organization was founded as the "European" Network, but already at the founding meeting Zimmerer proposed to rename it "International" Network or INoGS. At that meeting there followed a very intense discussion by the members present at the time, including former IAGS president Frank Chalk, who made particularly vivid and convincing comments as to why the name should not be changed. The membership voted decisively against the name change. Before long, however, and at least in a meeting with Chalk and me representing IAGS, Zimmerer made it clear that the vote of the members would be of no consequence to him, and the organization was formally renamed "International" subsequently without any further clarification by the membership.

While many of us continue to respect and appreciate Huttenbach's major contributions to genocide studies, we are deeply critical of his secretive and manipulative handling of the journal. In the meantime, under its present editorship, which involves INoGS leaders to a considerable extent, the journal publishes excellent articles and reviews, but there is also an aura of allowance of articles that are insulting to many of us genocide scholars with respect to Zionism and Israel for one; with respect to other issues in genocide studies, such as whether a professional association should or should not take value stands and/ or adopt resolutions about cases of genocide in the world; and by not accepting for review proposed reviews or letters by some people in the field who are viewed negatively by INoGS.

23. Samuel Totten and Steven Leonard Jacobs, eds., Pioneers of Genocide Studies (New Brunswick, NJ: Transaction, 2002).

24. Totten and Bartrop, Dictionary of Genocide.

25. Israel W. Charny, "Psychology of Genocide" [in Hebrew], International Problems 10 (1971): 41-7; Charny, "Normal Man as Genocider."

26. The psychologist and psychiatrist were Gilbert and Kelley, and each of them produced a significant book: G.M. Gilbert, The Psychology of Dictatorship: Based on an Examination of the Leaders of Nazi 
Germany (New York: Ronald Press, 1950); Douglas M. Kelley, 22 Cells in Nuremberg: A Psychiatrist Examines the Nazi Criminals (New York: Greenberg, 1947).

27. Christopher Browning, Ordinary Men: Reserve Battalion 101 and the Final Solution in Poland (New York: Harper-Collins, 1992).

28. Israel W. Charny, "Genocide and Mass Destruction: Doing Harm to Others as a Missing Dimension in Psychopathology," Psychiatry 49,2 (1986): 144-57; Israel W. Charny, "Evil in Human Personality: Disorders of Doing Harm to Others in Family Relationships," in Handbook of Relational Diagnosis and Dysfunctional Family Patterns, ed. Florence Kaslow (New York: Wiley, 1996), 477-95; Israel W. Charny, "A Personality Disorder of Excessive Power Strivings," Israel Journal of Psychiatry 34,1 (1997): 3-17; Israel W. Charny, Fascism and Democracy in the Human Mind: A Bridge between Mind and Society (Lincoln, NE: U of Nebraska P, 2006). Fascism and Democracy was awarded "Outstanding Academic Book of the Year" in 2007 by the American Library Association.

29. Stanley Milgram, Obedience to Authority: An Experimental View (New York: Harper \& Row, 1974). See also the excellent interpretations, experimental follow-ups, and assessments of Milgram's classic work in Thomas Blass, ed., Obedience to Authority: Current Perspectives on the Milgram Paradigm (Mahwah, NJ: Erlbaum, 2002).

Milgram formally defined his brilliant experimental series as "studies in conformity." They are also studies of human beings' readiness to do evil. However, the world of psychological science was not too welcoming of such conceptualizations, and although it is possible to see Milgram obliquely conveying in his writing that he is scientifically exploring behavior that very much has to do with the kinds of horrors the Nazis did, he does not dare say so explicitly. It is a matter of record that Milgram was not only hailed deservedly by many but was also mercilessly pilloried and denounced, ostensibly for the cruelty and what later came to be considered unethical stress that he imposed on his subjects. However, it has always seemed to me that the more powerful if unconscious meaning of the condemnations directed at Milgram resulted from his revealing our serious potential for evil-in some $66 \%$ of us, Milgram's experiments say.

30. Philip G. Zimbardo et al., "The Psychology of Imprisonment, Privation, Power and Pathology," in Theory and Research in Abnormal Psychology, ed. David Rosenhan and Perry London, 2nd ed. (New York: Holt, Rinehart \& Winston, 1975), 270-87; Philip G. Zimbardo and Alan Funt, Candid Camera Classics in Social Psychology: Viewer's Guide and Instructor's Manual (New York: McGraw-Hill, 1992); Philip G. Zimbardo, The Lucifer Effect: How Good People Turn Evil (New York: Random House, 2007).

Zimbardo's fiancée at the time of the Stanford experiment, Christine Maslach, a significant social psychologist in her own right, describes how she came to visit the site of the experiment and met a young man who charmed her with his graciousness and niceness. Later she discovered that this same young man became a nasty and cruel jailer in the experiment. The case was not isolated. At her insistence, the experiment was halted with the conclusion that too many normal people become dangerously cruel when given power over others. See Philip G. Zimbardo, Christina Maslach, and Craig Haney, "Reflections on the Stanford Prison Experiment: Genesis, Transformations, Consequences," in Blass, Obedience to Authority: Current Perspectives, 193-237.

31. For the original chart analyzing basic psychological processes and then applying these defined characteristics of human beings to definitions of early warning processes of genocide, see Charny and Rapaport, How Can We Commit the Unthinkable?, 344-7. Readers who are interested in receiving an unpublished expansion of this chart that was prepared in 2004 for a seminar at Hiroshima University are welcome to write to the author at encygeno@mail.com with a request.

32. I began my studies of genocide in 1963 in Philadelphia when I created a multidisciplinary group we called Group for Research in the Psychology of Aggression and Nonviolence, and I gave my first formal lecture at Gratz College in 1965. The lecture was later published as Israel W. Charny, "Teaching the Violence of the Holocaust: A Challenge to Educating Potential Future Oppressors and Victims for Nonviolence," Jewish Education 38 (1968): 15-24.

33. The challenge of getting prevention even on the IAGS agenda was evident in the conflict within IAGS over including "Prevention" in the title of the new journal (Genocide Studies and Prevention) launched jointly with the Zoryan Institute in 2006.

34. I first coined the concept of "definitionalism" in my presentation "A Proposal of a New Encompassing Definition of Genocide: Including New Legal Categories of Accomplices to Genocide, and Genocide as a Result of Ecological Destruction and Abuse," to the First Raphael Lemkin Symposium on Genocide, Mar 1991, Yale University Law School. The concept of multiple definitions of genocide is addressed in a chapter calling for a generic definition of genocide. See Israel W. Charny, "Toward a Generic Definition of Genocide," in Genocide: Conceptual and Historical Dimensions, ed. George Andreopoulos 
(Philadelphia: U of Pennsylvania P, 1994), 64-94. The concept is further developed in the entry in Israel W. Charny, "Classification of Genocide in Multiple Categories," in Charny, Encyclopedia, 3-9.

35. Ibid.; see also note 17 above.

36. The proposal for World Genocide Situation Rooms in genocide museums was made and little-noticed in an overwhelmingly noisy and overscheduled session at the International Symposium on the Holocaust convened by the Swedish government in Stockholm in Jan 2004. See Israel W. Charny, "Battling for an Anti-Genocidal World Culture" (paper presented at International Symposium on the Holocaust, 2004).

37. See GPN: Genocide Prevention Now 1 (winter 2010), http://www.genocidepreventionnow.org/Home/ GPNISSUES/Issue1Winter2010.aspx (accessed 15 Feb 2012). GPN is a Web magazine in its third year of publication. The four issues of 2010 are now scheduled to be republished in a hardcover book by Gorgias Press. The idea of such a site that would combine information about genocide in the world, genocide studies, and prevention efforts was also first presented but little-noticed at the International Symposium on the Holocaust convened by the Swedish government in Stockholm in 2004. See Israel W. Charny, "Battling for an Anti-Genocidal World Culture." Here then is an example of one idea that has since been successfully brought to life, in this case with the kind assistance and support of the Carnegie Corporation of New York. Once again in light of the anthem of this article, I want to encourage genocide scholars to dream and pursue dreams and ideas of innovations that might advance the field to greater power as a force of genocide prevention in our real world.

38. A sequence of articles about laws against denials of the Holocaust and genocide has recently been published in GPN: Genocide Prevention Now. See Michael J. Bazyler, "Holocaust Denial Laws and Other Legislation Criminalizing Promotion of Nazism," GPN 1 (winter 2010), http://www.genocidepreventionnow.org/Home/GPNISSUES/Issue1Winter2010/tabid/72/ctl/DisplayArticle/mid/525/aid/195/Default. aspx (accessed 15 Feb 2012); Jacqueline Lechtholz-Zey, "The Laws Banning Holocaust Denial," GPN 3 (summer 2010), http://www.genocidepreventionnow.org/Home/GPNISSUES/Issue3Summer2010/tabid/ 70/ctl/DisplayArticle/mid/460/aid/153/Default.aspx (accessed 15 Feb 2012); Roger W. Smith, "Legislating Against Genocide Denial: Criminalizing Denial or Preventing Free Speech?” GPN 6 (spring 2011), http://www.genocidepreventionnow.org/Home/GPNISSUES/Issue6Spring2011/tabid/109/ctl/DisplayArticle/mid/688/aid/209/Default.aspx (accessed 15 Feb 2012); Israel W. Charny, "Fire, Fire and Legislating Denials of Holocaust and Genocide: Tolerable Free Speech or Criminal Incitement to Violence?" GPN 6 (spring 2011), http://www.genocidepreventionnow.org/Home/GPNISSUES/Issue6Spring2011/tabid/109/ ctl/DisplayArticle/mid/688/aid/218/Default.aspx (accessed 15 Feb 2012).

39. Israel W. Charny, Fighting Suicide Bombing: A Worldwide Campaign for Life (Westport, CT: Praeger Security International, 2007).

40. Israel W. Charny, " $R 2$ L ! Proposing a Worldwide Union of Genocide Victim Peoples-and All Caring People-On Behalf of a Right to Life of All People" (paper presented at The Crime of Genocide: Prevention, Condemnation and Elimination of Consequences, the International Conference in Yerevan, Armenia, Dec 2010). The proposal of R2L was presented for the first time to the International Conference, Three Genocides, One Strategy, in Athens, September 2010). The organizers of the conference, who constitute an ongoing organization that is planning to hold another conference in Stockholm, announced that they had resolved to support the proposed development of R2L. The text of the paper presented in Athens is also available in GPN: Israel W. Charny, "The Psychology of Denying Other Victims of a Genocide: A Quest for Exclusivity and Superiority-Disturbingly, Not unlike Similar Motives in Those who Commit Genocide," GPN: Genocide Prevention Now 5 (Winter 2011), http://www.genocidepreven tionnow.org/Home/SPECIALISSUE5ARMENIANGENOCIDECOVICTIMS/tabid/101/ctl/DisplayArticle/ mid/607/aid/245/Default.aspx (accessed 6 Feb 2012).

41. Gareth Evans, The Responsibility to Protect: Ending Mass Atrocity Crimes Once and For All (Washington DC: Brookings Institution Press, September 2008); Gareth Evans and Mohamed Sahnoun, "The Responsibility to Protect," Foreign Affairs (Nov/Dec 2002), http://www.foreignaffairs.com/author/gareth-evans (accessed 8 Jul 2010).

42. Quoted in Search Quotes, http://www.searchquotes.com/quotation/We_love_death._The_U.S._loves_ life._That_is_the_difference_between_us_two./123789/(accessed 14 Feb 2012).

43. To the best of my knowledge, the first scholar to call theoretical attention to the fact that victim peoples too have been genociders is Nicholas Robins who has studied genocide and native peoples and noted that there are also cases in which Indians were the perpetrators. He also makes the important observation that this dimension of human history is often obscured. Nicholas A. Robins, Genocide and Millennialism in Upper Peru: The Great Rebellion of 1780-1782 (Westport, CT: Praeger, 2002). 